\title{
A PRÁTICA ESCANCARADA DA TORTURA: AS VIOLAÇÕES AOS DIREITOS HUMANOS DURANTE A DITADURA CIVIL MILITAR BRASILEIRA
}

\author{
Ivo dos Santos Canabarro * \\ Luane Flores Chuquel **
}

\begin{abstract}
Resumo: Este artigo se resume em analisar as violações aos direitos humanos durante a Ditadura militar brasileira (1964-1985), bem como os métodos e práticas de torturas. O problema central analisa de que forma as violações dos direitos humanos influenciam no resgate histórico nacional? A hipótese, preliminarmente, coaduna-se que a verdade histórica brasileira deve ser buscada para a efetivação da memória como forma de conhecer e conscientizar as presentes e as futuras gerações. Objetiva-se, conhecer e denunciar os métodos praticados pelo governo militar brasileiro e a forma de se fazer tortura. Utilizou-se o método científico hipotético-dedutivo ou dedutivo-falseável e o procedimento monográfico.
\end{abstract}

Palavras-chave: Direitos Humanos; Ditadura Militar; Resgate Histórico; Tortura; Violações;

\section{THE SCANED PRACTICE OF TORTURE: VIOLATIONS TO HUMAN RIGHTS DURING THE BRAZILIAN MILITARY CIVIL DICTATORSHIP}

\begin{abstract}
This article summarizes the analysis of human rights violations during the Brazilian military dictatorship (1964-1985), as well as the methods and practices of torture. The central problem analyzes how human rights violations influence national historical redemption? The hypothesis, preliminarily, is that the Brazilian historical truth must be sought for the effectiveness of memory as a way of knowing and raising awareness of present and future generations. Objective, know and denounce the methods practiced by the Brazilian military government and the way of doing torture. The hypothetical-deductive or deductivefalsifiable scientific method and the monographic procedure were used.
\end{abstract}

Keywords: Human RightsMilitary dictatorshipHistorical RedemptionTortureViolations;

\section{INTRODUÇÃO}

Durante o regime militar brasileiro (1964 a 1985), o cenário político-social era deplorável, onde normas e garantias constitucionais e fundamentais foram corrompidas de maneira brutal e disforme. Disforme no sentido de violar normas e premissas fundamentais de

\footnotetext{
*Pesquisador associado a Organização das Nações Unidas para a Educação, a Ciência e a Cultura- UNESCO na Cátedra Diversidade Cultural, Gênero e Fronteiras. Pós doutorado em História Social pela Universidade Federal Fluminense. Doutorado em História pela Universidade Federal Fluminense - UFF, com Estágio de Doutorado na Université Paris III Sorbonne Nouvelle, Instituto de Cinema Audiovisual com orientação de Philippe Duhois. Mestrado em História do Brasil pela Universidade Federal do Rio Grande do Sul - UFRGS, professor no PPGD (Mestrado em Direitos Humanos) da Universidade Regional do Noroeste do Estado do Rio Grande do Sul UNIJUI, Ijuí/RS, RS E-mail: ivo.canabarro@unijui.edu.br.

** Bacharel em Direito pela Universidade Regional Integrada do Alto Uruguai e das Missões - URI, campus Santo Ângelo/RS. Mestranda em Direitos Humanos na Universidade Regional do Noroeste do Estado do Rio Grande do Sul - UNIJUÍ, Ijuí/RS. Bolsista CAPES, e-mail.: luanechuquel@ hotmail.com.
}

Revista Brasileira de Direitos e Garantias Fundamentais | e-ISSN: 2526-0111 | Porto Alegre | v. 4 | n. 2 | p. 18 - 37 | Jul/Dez. 2018 
proteção aos direitos individuais e coletivos e, principalmente, o desrespeito e violações aos direitos humanos.

A pesquisa histórica científica tem como tema as violações aos direitos humanos durante a Ditadura militar brasileira (1964-1985), e, como prisma principal, a análise dos métodos e práticas de torturas. A abordagem dessa temática é de grande relevância, pois abarca em sua concepção o viés social e humano, na medida em que se verifica a existência da violação de um direito humano, há o estrito cumprimento do dever legal em corrigir este erro, a fim de que nunca mais aconteça.

A partir desta síntese, o problema à frente desta pesquisa concentra-se no questionamento: de que forma o estudo sobre as violações dos direitos humanos ocorridos durante a ditadura militar no Brasil influenciam no resgate histórico nacional?

A hipótese que se vislumbra, inicialmente, coaduna-se de que a verdade histórica brasileira deve ser buscada para a efetivação da memória como forma de conhecer, reconhecer e conscientizar as presentes e as futuras gerações como meio de se fazer justiça. Tem-se, por fim, evitar que os eventos passados não se repitam, assegurando, difundido e garantindo o respeito aos direitos humanos.

Nesse sentido, tem-se como objetivo geral estudar, conhecer e denunciar os métodos praticados pelo governo militar brasileiro e a forma de se fazer tortura. Analisar e apontar que a prática da tortura foi uma das formas mais cruéis de violar direitos naquele nefasto período.

Para tanto, adota-se o método científico hipotético-dedutivo ou dedutivo-falseável, de Karl Popper, por entendê-lo mais apropriado à pesquisa pretendida. Ao lado do método de abordagem, opta-se, como método de procedimento, pelo método monográfico, o qual se utilizará, paralelamente, de uma visão panorâmica de outras temáticas correlatas, pois necessárias e imprescindíveis ao estudo da temática escolhida, na medida em que informem, justifiquem, estruturem ou deem sentido ao tema central.

Operacionalizar-se-á tais métodos na medida em que se pesquisará sobre uma temática específica e bem delimitada, falseando-se as hipóteses suscitadas, por meio do emprego de vasta pesquisa bibliográfica, utilizando-se da doutrina existente acerca da temática proposta - livros e periódicos -, do fichamento e do apontamento.

Nesse contexto, a presente pesquisa, divide-se em duas partes, abordando-se, respectivamente, a analise dos registros históricos sobre as violações aos direitos humanos 
durante a ditadura civil militar brasileira ao denunciar as práticas de torturas. Abordar-se-á, outrossim, acerca dos métodos e práticas utilizadas como meio de tortura.

\section{A PRÁTICA DA TORTURA NA DITADURA MILITAR}

"[...] a tortura é prática comum para extrair confissões, para humilhar, para amedrontar, para fazer cumprir uma ordem. Durante a ditadura militar, implantada pelo golpe de 1964, a tortura foi um ato de Estado e uma política sistemática”.

(ARANTES, 2008, p.76)

A tortura enquanto política sistemática implantada nos quartéis e aplicada durante o regime de exceção em opositores políticos ${ }^{3}$ produziu graves violações aos Direitos Humanos. Isso porque a tortura foi o principal método utilizado para extrair confissões e informações verdadeiras, ou, ainda, a forçar o preso a prestar depoimentos forjados e a fazer declarações falsas.

Salienta-se que a tortura começou a ser praticada nos primeiros momentos após a decretação do golpe militar brasileiro, porém concretizou-se após os anos de 1968 (FICO, 2004, p.33). Nesse lapso temporal, a tortura foi “[...] usada com regularidade por diversos órgãos da estrutura repressiva, entre delegacias e estabelecimentos militares, bem como em estabelecimentos clandestinos em diferentes espaços do território nacional" 4 (COMISSÃONACIONAL DA VERDADE, 2014, p.343).

A partir da implantação do Ato Institucional $n^{\circ} 05^{5}$, " “[... a tortura ${ }^{6}$ se tornou uma política oficial de Estado", servindo de instrumento para o controle social do Estado, onde "[...] muitos opositores políticos foram torturados", pois em defesa da ordem nacional, segundo o imaginário político governamental (COIMBRA, 2001, p.07).

Estudos estatísticos apontam que cerca de 56\% (cinquenta e seis por cento) dos presos a partir da implantação do AI-5 eram "[...] estudantes universitários ou detentores de um diploma de nível superior" (OLIVEIRA, 2011, p.11). O perfil dos torturados, no entanto, advinda das mais variadas classes sociais, a saber: sindicalistas, esposas de aprisionados,

\footnotetext{
${ }^{3}$ Estes eram selecionados independentemente de idade, gênero, raça, cor, religião ou, ainda, situação moral, psicológica e física, sendo violentados fisicamente, psicologicamente e sexualmente durante o regime civil militar brasileiro (1964 a 1985).

${ }^{4}$ Isso porque, “[...] não há padronizações, só adaptações e improvisos. [...]. Precários ou não, pouco importa: o importante é que você não se sinta em casa" (MATTOSO, 1984, p.13).

${ }^{5}$ Criado em 13 de dezembro de 1968, durante o governo de Médici (1969-1974), “[...] momento em que mais se torturou em nosso país" (COIMBRA, 2001, p.07).

${ }^{6}$ Sob a ótica dos militares tratava-se como um "[...] mal menor".
}

Revista Brasileira de Direitos e Garantias Fundamentais | e-ISSN: 2526-0111 | Porto Alegre | v. 4 | n. 2 | p. $18-37$ | Jul/Dez. 2018 
professores universitários e/ou de educação básica, políticos, mulheres grávidas, estudantes, sindicalistas, crianças, profissionais liberais, membros da igreja católica, jornalistas, artistas que sofriam repressão, dentre outros (ARNS, 1987, passim).

Por outro lado, o torturador era todo o funcionário público, enfermeiro, médico e médico-legal atuando em estrito cumprimento do dever legal e em prol da segurança nacional. Segundo a Comissão Nacional da Verdade, a prática da tortura:

\begin{abstract}
pode decorrer da ação daqueles que a cometem diretamente, como também daqueles que ordenam, instigam ou induzem sua execução; bem como da omissão daqueles que, podendo impedi-la, não o fazem, como determina a Convenção Interamericana para Prevenir e Punira Tortura. [...]. No caso brasileiro, participaram médicos e enfermeiros nos atos da tortura ou na produção de laudos falsos. Compreende-se que existe participação ou responsabilidade de um médico no ato de tortura, entre outras circunstâncias, quando o profissional participa diretamente desse ato; ou emite certificação médico-forense de uma pessoa torturada, ou de seus restos mortais, na qual omite descrições de lesões ou elementos pertinentes para a perícia e relevantes para a adequada investigação do caso. [...] ignorar deliberadamente as provas de tortura; e falsificar relatórios, como autópsias ou certidões de óbito (COMISSÃO NACIONAL DA VERDADE, 2014, p.286-287).
\end{abstract}

Logo, os agentes públicos não se contentavam em apenas causar dores físicas nos torturados, mas sim mexer com o emocional, como se a dor "[...] fizesse entrar em conflito com o próprio espírito e pronunciar o discurso que, ao favorecer o desempenho do sistema repressivo, significasse sua sentença condenatória”. Nesse sentido, familiares das vítimas eram alvos da repressão política-militar:

\begin{abstract}
Os familiares diretos das vítimas de graves violações de direitos humanos podem ser considerados também, eles próprios, vítimas. Especialmente nos casos de desaparecimento forçado, estima-se que suas circunstâncias violam a integridade pessoal dos familiares diretos por gerarem sofrimento e angústia, ademais de um sentimento de insegurança, frustração e impotência ante a abstenção das autoridades de investigar os fatos, em detrimento da integridade psíquica e moral dos familiares. Em relação aos familiares diretos, opera-se com uma presunção de violação à integridade pessoal (COMISSÃO NACIONAL DA VERDADE, 2014, p.286).
\end{abstract}

Nesse diapasão, somente o fato de a mulher estar grávida, torna-se totalmente vulnerável; a criança indefesa torna-se alvo fácil e as esposas de aprisionados eram "alvos" de aplicação e prática de tortura, pois, segundo a análise de ARNS, havia uma “[...] urgência de se obter informações", uma vez que:

a tortura visava imprimir à vítima a destruição moral pela ruptura dos limites emocionais que se assentam sobre relações efetivas de parentesco. Assim, crianças

Revista Brasileira de Direitos e Garantias Fundamentais | e-ISSN: 2526-0111 | Porto Alegre | v. 4 | n. 2 | p. $18-37$ | Jul/Dez. 2018 
foram sacrificadas diante dos pais, mulheres grávidas tiveram seus filhos abortados, esposas sofreram para incriminar seus maridos (1987, p.43).

A partir “[...] dos métodos inquisitoriais, a tortura - nos anos 60, 70 [...] - persegue também a verdade, onde a confissão do supliciado é procurada a todo o custo", a exemplo do caso supramencionado. Isso não significa dizer que, uma vez falando a verdade, o torturado estará absolvido de sofrer tortura, ou ainda, assegurado ao direito a vida. Ao contrário, “[...] muitos após terem "confessados" foram [...] mortos ou desaparecidos" (COIMBRA, 2001, p.07).

Alguns dos métodos utilizados para dar início às seções das sevícias era a utilização do capuz. Logo, ao empregar este material em um preso, este deverá ser “[...] conduzido pela mão, como um cego" (MATTOSO, 1984, p.12). Como resultado, tem-se a ausência de agressividade por parte do preso, uma vez que sua cabeça está coberta, tornando-se uma "presa fácil" ao ato de prender.

\begin{abstract}
A tortura é antes de tudo um choque, uma surpresa. Por mais que você pense estar preparado para uma situação dessas, vai estranhar logo de cara com o ambiente. Para que o ambiente seja estranho ao máximo, é preciso que não saiba exatamente onde está. Daí o primeiro fator comum à maioria dos depoimentos: o olho vendado. Às vezes até durante a sessão, às vezes só até chegar à oficina. Uma máscara já dá para desorientar, mas um capuz é mais usado (de fato, é raro ver um capuz novo), geralmente complementado pela manietação ${ }^{7}$ (MATTOSO, 1984, p. 12, grifo do autor).
\end{abstract}

A ordem era cobrir o que estava descoberto e descobrir o que estava coberto. Com a aplicação dessa medida, tem-se um preso encapuzado e despido. Logo, há o início do emprego da tortura psicológica ${ }^{8}$, em razão do apavoramento, medo e angústia do preso, pois indefeso. Segundo o pensamento de Mattoso:

\begin{abstract}
A nudez é o segundo fator comum. Logicamente uma pessoa trajada atrapalha o trabalho de qualquer torturador, mas o efeito imediato da nudez, antes de facilitar as coisas para o carrasco, é dificultar para você. Pelado você está mais indefeso, e ainda por cima acanhado. Ou seja, além de desnorteamento, a vergonha e o medo. Bons ingredientes para a confusão mental. [...]. O medo é tão fundamental que, na Inquisição, os dois primeiros graus da tortura eram ameaçá-lo de ser torturado e levá-lo até a câmara da tortura (MATTOSO, 1984, p.13-14, grifo do autor).
\end{abstract}

\footnotetext{
${ }^{7}$ Segundo dicionário português, a palavra manietação significa perder; envolver. Exemplifica-se da seguinte maneira: "A cerca, ela está ali, alta, intransponível... A cerca,... impedindo-lhe a evasão, tolhendo-lhe os passos, manientando-a" (FERREIRA, 2010, p.1327).

8 "[...] pode ser compreendida como aquela na qual a violência, mais do que atingir e deixar marcas no corpo da vítima, produz danos psicológicos (mentais)" (COMISSÃO NACIONAL DA VERDADE, 2014, p.376).
} 
Somado a isso, o preso é jogado em um cárcere privado, onde passa por necessidades básicas, violando a dignidade da pessoa humana, pois há a ausência de conforto, "[...] a falta de higiene, a falta de luz, a falta de calor ou de ar fresco", a falta de alimentação e a sede, além da presença da insônia. Caracterizando, assim, a presença de tortura psicológica, visto que:

as privações que podem definhá-lo lentamente e alterar-lhe não só a fisionomia como a personalidade: a fome que pode obrigá-lo a comer coisas que você nem cheiraria; a sede, que força a beber aquilo que já foi bebido; e a insônia forçada, que lhe provoca alucinações e pode pirar (MATTOSO, 1984, p.25, grifo do autor).

Não obstante, os militares aplicavam sob os torturados a ordem do medo e do terror, pois havia o emprego de execuções falsas e as vítimas eram forçadas a presenciar a prática da tortura em outras pessoas. Outrossim, atos degradantes e de extrema precariedade era presenciado no âmbito dos quartéis, a exemplo, o número de aprisionados em uma cela que não comportava com a estrutura física do local.

ameaçá-lo de morte e fingir que vão executá-lo; obrigá-lo a ouvir e ver outras pessoas (talvez de sua família) sendo torturadas; mantê-lo em isolamento e silêncio total ou ensardinhá-lo numa cela apinhada de gente em pé, debaixo de barulheira ensurdecedora; enfim, deixá-lo na simples expectativa de que lhe aconteça tudo aquilo de novo, na mesma bat-hora e no mesmo bat-canal ou a qualquer momento em edição extraordinária (MATTOSO, 1984, p.26-27).

Concomitantemente surgem os primeiros sinais de agressões físicas ${ }^{9}$, ou melhor, "preparativos" para que isso ocorra consistentes em "[...] golpes com as mãos e os pés. A bofetada, também tapa ou tabefe, que arde mais na hora do que na bochecha ${ }^{10}$. O murro ou soco ${ }^{11}$, que pode nocautear, e o chute ou pontapé, que pode matar". Todas essas práticas eram sofridas pelos torturados, todavia, para os torturadores era motivo de divertimento e chacota (MATTOSO, 1984, p.14, grifo do autor).

Para a Comissão Nacional da Verdade, a “[...] Tortura em caso de detenção (prisão)” constitui:

\footnotetext{
9 “[...] praticada nas mais diversas formas e por meio de distintos instrumentos, agindo, em regra, sobre o corpo do torturado" (COMISSÃO NACIONAL DA VERDADE, 2014, p.366).

${ }^{10}$ Que poderia ser aplicado com "um golpe de caratê, e o braço pode estar prolongado por um cassetete ou coisa que o valha" (MATTOSO, 1984, p.15).

11 “[...] reforçado por um soco-inglês" (MATTOSO, 1984, p.15).
}

Revista Brasileira de Direitos e Garantias Fundamentais | e-ISSN: 2526-0111 | Porto Alegre | v. 4 | n. 2 | p. $18-37$ | Jul/Dez. 2018 
adoção de medidas que restrinjam a liberdade do detido além do nível de sofrimento estritamente necessário e intrínseco à detenção, tais como: imposição de isolamento em cela reduzida, sem ventilação ou luz natural; restrição ao regime de visitas; intimidação como ameaça de atos violentos; violência física contra a vítima; exibição do preso nu ou em trajes que o exponham; e má prestação de serviços básicos,como atenção médica, alimentação e higiene. Também se considera tortura a submissão do detido ao isolamento prolongado e à incomunicabilidade coercitiva (2014, p.285).

Estando a vítima encapuzada, nua e sofrida as primeiras agressões psicológicas e físicas, é chegada a hora de ser colocado em prática o mecanismo das sevícias brutais e disformes. Para isso, eram realizadas diversas maneiras de espancamento, com o emprego de pau-de-arara, choque elétrico, afogamento, bem como a utilização de insetos, animais e produtos químicos, dentre outras maneiras e instrumentos de tortura.

O pau-de-arara ${ }^{12}$ consistia em uma barra de madeira ou cano de ferro, apoiado sobre duas mesas ou cavaletes e, com o auxílio de uma corda, entrelaçava os punhos e os pés, o amarrando, ficando a vítima pendurada de cabeça para baixo "[...] a cerca de 20 ou $30 \mathrm{~cm}$ do solo" (ARNS, 1987, p.34).

Assim, o aprisionado estava suspenso no ar e, "[...] além das dores provocadas pelo próprio "pau-de-arara" - devido à tração e à paralisação da circulação nos membros inferiores e superiores -, fica completamente à mercê dos interrogadores", vulnerável à execução de tortura, nada podendo fazer em sua defesa (MATTOSO, 1984, p.17-18).

Segundo explana Glauco Mattoso, “[...] no pau-de-arara o torturado vê as coisas de cabeça para baixo. Para ele tudo é inverso em relação ao torturador, a começar pela posição. Se o carrasco pode ter sido previamente doutrinado, do ponto vista da vítima a prática vem antes da teoria (1984, p.11).

Dentre outras formas, está o uso da eletricidade que, sem dúvida era a mais utilizada, era construída a partir de:

Um dínamo comum (tipo magneto do telefone de campanha), acionado por uma manivela constitui a famosa maquininha de choque conhecida como pimentinha, perereca ou maricota. Conforme a velocidade imprimida à manivela, a voltagem aumenta ou diminui, e os fios podem ser cuidadosamente presos a partes sensíveis do seu corpo (ânus, glande, vagina, língua, dentes, dedos, tímpanos). (MATTOSO, 1984, p.25, grifo).

\footnotetext{
${ }^{12}$ Método eficaz e "adotado nos porões da ditadura - tão característico daqueles anos a ponto de ter se tornado símbolo do movimento Tortura Nunca Mais” (OLIVEIRA, 2011, p.10).
} 
Atrelado à prática de choques elétricos presos a partes sensíveis ao corpo da vítima, causando maior lesividade corporal, está o uso da “[...] cadeira do dragão". Esse procedimento consistia em:

uma cadeira extremamente pesada, cujo assento é de zinco, e que na parte posterior tem uma proeminência para ser introduzido um dos terminais da máquina de choque chamado magneto; que, além disso, a cadeira apresentava uma travessa de madeira que empurrava as suas pernas para trás, de modo que a cada espasmo de descarga as suas pernas batessem na travessa citada, provocando ferimentos profundos (ARNS, 1987, p.36).

Se não o bastasse, havia ainda o emprego de água, fogo e animais utilizados como ferramentas para a prática da tortura, sendo ““[...] complementos” do pau-de-arara” (ARNS, 1987, p.36). A água era utilizada de diversas maneiras, podendo ser misturada com urina, fezes, “[...] sabão, sal, querosene ou amoníaco”.

Uma simples gota pingando continuamente no alto do seu cocuruto pode deixá-lo desmiolado. Guindado de ponta-cabeça num volume dela, você pode ser afogado e reanimado sucessivamente até o limite da resistência. Ingerida em quantidade pode inchá-lo até arrebentar. Injetada nas narinas também pode afogar, e em jato de mangueira equivale a uma surra. Gelada o resfria e mata; quente o escalda; estagnada e podre pode podar-lhe o pé; [...] O afogamento é tão frequentemente aplicado quanto são inúmeras suas variações. Pendurado no pau, você pode ser submetido ao submarino, isto é, sua cabeça fica totalmente submersa em água, urina ou fezes; pode entrar pela hidráulica, ou seja, enquanto sua boca está amordaçada a água é despejada em suas narinas através de canudos ligados a um funil; ou pode agüentar o caldo, a saber, agora suas narinas é que são tapadas e você tem que engolir uma mangueira que lhe esguicha lá dentro em alta pressão (MATTOSO, 1984, p.21-22, grifo do autor).

Segundo comparativo de Mattoso, a utilização do fogo ocupa “[...] lugar secundário e exercem função acessória. [...]. Preocupe-se apenas com ser chamuscado aqui e ali por pontas de cigarro e charuto, com a famosa vela supositória, ou até mesmo com um maçarico nas nádegas” (1984, p.23). No tocante à fauna, animais como jacarés, cães, jiboias, “[...] ratos, baratas, piolhos e pulgas" eram utilizados pelos milicianos como métodos de tortura.

o rato pode ser colocado dentro de um penico, no qual você tem que sentar e ao qual é amarrado. Aquecido o penico, o resto (ou o reto) é por conta do rato. Outro exemplo: se seu corpo for untado de mel (ou algo mas falsificado), as moscas, vespas e formigas ficarão assanhadinhas por você (MATTOSO, 1984, p.23/24).

Revista Brasileira de Direitos e Garantias Fundamentais | e-ISSN: 2526-0111 | Porto Alegre | v. 4 | n. 2 | p. $18-37$ | Jul/Dez. 2018 
Outro método muito utilizado era a tortura sexual praticado "[...] por agentes de Estado (ou terceiros atuando com a conivência estatal) para, entre outras razões, anular a personalidade da vítima”. Segundo o entendimento da Comissão Nacional da Verdade,

caracteriza-se como os atos de natureza sexual cometidos contra uma pessoa sem seu consentimento. Abrange tanto a violação física do corpo humano- a penetração vaginal, anal ou oral, com partes do corpo do agressor ou com objetos -como os atos que não imponham penetração ou sequer contato físico, como o desnudamento forçado e a revista íntima. Estaria aí contemplado também o uso de animais nas genitálias [...] (2014, p.286).

Instado no pau-de-arara, o homem poderá sofrer a “[...] tortura dita sexual", consistente em:

\begin{abstract}
Magoar os pompons ou o orifício, preferencialmente a quaisquer outras partes do corpo. Você pode ser apaleado no pau e nos testículos ou ser empalado por um cassetete, uma garrafa, um taco de bilhar, uma cenoura, um cabo de vassoura e até mesmo uma vela (que logicamente será acesa) (MATTOSO, 1984, p.18).

introduzido no ânus pelas autoridades policiais um objeto parecido com um limpador de garrafas (ARNS, 1987, p.40).
\end{abstract}

Por outro lado, a mulher era violada, "[...] e até forçada a 'participar' do ato praticando felações, carícias e coisas do gênero". A prática de atos libidinosos ${ }^{13}$ diversos da conjunção carnal ${ }^{14}$ ocorria de maneira habitual com sessões de “[...] torturas vaginais e nos seios" (MATTOSO, 1984, p.18). Ainda:

A Convenção Interamericana para Prevenir, Punir e Erradicar a Violência contra a Mulher considera violência contra a mulher qualquer ato ou conduta baseado no gênero que cause morte, dano ou sofrimento físico, sexual ou psicológico à mulher (COMISSÃO NACIONAL DA VERDADE, 2014, p.286).

Por outro lado, a chamada tortura química era aplicada com o fim de "[...] alterar o seu estado físico e psíquico". Isto é, qualquer espécie "[...] de produto químico contra o torturado, seja para fazer falar, por alteração da consciência, seja para provocar dor, para assim obterem a informação desejada" (COMISSÃO NACIONAL DA VERDADE, 2014, p.360).

13 “[...] compreende outras formas de realização do ato sexual, que não a conjunção carnal. São os coitos anormais (por exemplo, a cópula oral e anal), os quais constituíam o crime autônomo de atentado violento ao pudor (CP, antigo art.214). Pode-se afirmar que ato libidinoso é aquele destinado a satisfazer a lascívia, o apetite sexual" (CAPEZ, 2012, p.25-26).

14 “[...] é a cópula vagínica, ou seja, a penetração efetiva do membro viril na vagina” (CAPEZ, 2012, p.25).

Revista Brasileira de Direitos e Garantias Fundamentais | e-ISSN: 2526-0111 | Porto Alegre | v. 4 | n. 2 |

p. 18 - 37 | Jul/Dez. 2018 
Nesse sentido, diversas drogas eram "[...] misturadas na comida, na água, respiradas, clisteradas, injetadas, tais como o soro-da-verdade ${ }^{15} \mathrm{e}$ processos análogos à narcoanálise" (MATTOSO 1984, p.27). Dessa maneira, têm-se quatro categorias distintas classificadas e reconhecidas como método oficial de tortura utilizado durante o regime militar brasileiro: psicológica, física, sexual e a química, praticados por agentes públicos do estado.

Nesse diapasão, conclui-se que a tortura foi utilizada pelos militares de maneira brutal, disforme, covarde e abusiva contra os cidadãos brasileiros que, independentemente de idade, gênero, raça, cor, religião ou, ainda, situação moral, psicológica e física foram violentadas fisicamente, psicologicamente e sexualmente durante o regime militar brasileiro (1964 a 1985).

Objetivou-se, contudo, denunciar as atrocidades cometidas durante esse nefasto período, utilizando-se da tortura como uma dos principais desconsiderações dos direitos humanos. Por essa razão, urge a necessidade de analisar as violações aos direitos humanos ocorridos neste período, objeto de estudo a seguir.

\subsection{VIOLAÇÕES AOS DIREITOS HUMANOS NO PERÍODO MILITAR}

"Não há direitos humanos sem democracia, nem tampouco democracia sem direitos humanos"

(PIOVESAN, 2014, p. 205).

Durante o regime militar ditatorial, normas e premissas fundamentais foram violadas e direitos individuais indisponíveis foram brutalmente suprimidos. Neste lapso temporal, a prática da tortura era sistematicamente aplicada, as detenções eram arbitrárias, os desaparecimentos forjados, a censura impiedosamente repressiva e a "[...] perseguição político-ideológica" era realizada de maneira clandestina (PIOVESAN, 2014, p.545).

Segundo informações prestadas pela Comissão Nacional da Verdade, a ruptura dos direitos humanos consistiu em:

opositores políticos do regime - e todos àqueles que de alguma forma eram percebidos por este como seus inimigos - foram perseguidos de diferentes maneiras. Os exemplos são muitos: cassação de mandatos eletivos e de cargos públicos censura e outras restrições à liberdade de comunicação e expressão, punições

\footnotetext{
${ }^{15}$ Trata-se de um "pentotal sódico [...], isto é, um barbiturato (os barbitúricos e outros hipnóticos produzem um efeito progressivo, primeiro sedativo e, em seguida, de anestesia geral e, finalmente, de depressão gradativa dos centros bulbares)" (COMISSÃO NACIONAL DA VERDADE, 2014, p.370).
}

Revista Brasileira de Direitos e Garantias Fundamentais | e-ISSN: 2526-0111 | Porto Alegre | v. 4 | n. 2 | p. 18 - 37 | Jul/Dez. 2018 
relativas ao exercício da atividade profissional (transferências, perda de comissões, afastamento, demissões) e exclusão de instituições de ensino (2014, p.278).

Reconhece-se, outrossim, outros métodos utilizados no período ditatorial como violação aos direitos humanos, a saber: à prisão ilegal e arbitrária; à prática de violência sexual; “[...] tortura; execução sumária, arbitrária ou extrajudicial e outras mortes imputadas ao Estado; e desaparecimento forçado" (COMISSÃO NACIONAL DA VERDADE, 2014, p.278-280).

Nesse contexto político, opositores do regime ditatorial tiveram seus direitos políticos cassados e suas famílias vigiadas.

Todo um aparato técnico de informações e ações organizadas foi montado e colocado a serviço de crimes em massa como: prisões arbitrárias sem direito a qualquer contraditório ou garantia; torturas e sevícias cruéis que deixaram sequelas permanentes ou resultaram em mortes; seqüestros de crianças, pais, mães e filhos; assassinatos e desaparecimentos; monitoramentos e ameaças constantes que resultavam em prisões e mortes; banimentos e pessoas compelidas ao exílio; a descartabilidade de qualquer garantia ou qualificativo jurídico (SILVA FILHO, 2008, p.156).

Essa afirmativa também merece respaldo, em razão de estar presente na percepção de outros autores ao relatar que:

\begin{abstract}
Milhares de pessoas foram prejudicadas - além daquelas que foram obviamente atingidas pela tortura, pela violência explícita. Crianças foram separadas de seus pais. Jovens foram impedidos de estudar. Profissionais qualificados tiveram suas carreiras destruídas. Esposas, maridos, filhos, pais e avós foram massacrados psicologicamente pela crueldade do "desaparecimento" (FICO, 2012, p.58).
\end{abstract}

Não obstante, quem se opusesse aos preceitos do regime ditatorial por meio da imprensa, teatro, música, literatura ou das artes, ou mesmo possuísse amizades com políticos influentes exilados, eram duramente censurados, torturados e exilados.

\begin{abstract}
A censura da imprensa acompanhou o auge da repressão (quando se pensa em cassações de mandatos parlamentares, suspensões de direitos políticos, prisões, torturas e assassinatos políticos) que se verificou entre finais dos anos 60 e início dos anos 70. A censura de diversões públicas, porém, teve seu auge no final dos anos 70, já durante a "abertura" (FICO, 2004, p.37).
\end{abstract}

Observa-se que durante o regime militar brasileiro houve a ruptura desses direitos básicos que deveriam ser tutelados pelo Estado, como, por exemplo, normas fundamentais à dignidade da pessoa humana que, no entanto, não eram zelados. Por assim dizer, "A tortura, 
as perseguições e assassinatos praticado pelo Estado e por grupos paramilitares" foram uma prática comum no Brasil (MAGALHÃES, 2000, p.35). Nesse diapasão:

La tortura es una violación fundamental de los derechos humanos, condenada por La comunidad internacional como una ofensa a la dignidad humana y prohibida en toda circunstancia por El derecho internacional (AMNISTÍA INTERNACIONAL, 2001, p.109).

Durante o regime militar, cerca de dezessete Atos Institucionais foram baixados, dentre eles, destacam-se com o "[...] objetivo de reforçar o Poder Executivo e reduzir o campo de ação do Congresso" "16, reforçar os poderes do Presidente da República ao estabelecer plenos poderes para decretar atos complementares, bem como "[...] decretos-leis em matéria de segurança nacional" ${ }^{17}$. Realizar eleições indiretas para governadores de Estado ${ }^{18}$, ampliar os poderes executivos, especialmente ao que tange a segurança nacional ${ }^{19}$. Ainda, no governo de Costa e Silva, houve o "[...] instrumento de uma revolução dentro da revolução" 20 (FAUSTO, 1999, p.466, p.474-475 e p.480).

Após o ardiloso período de 21 anos em que o governo brasileiro estava sob o comando das forças armadas, perdurando entre os anos de 1964 a 1985, iniciou-se, sob o comando do general Ernesto Geisel um processo “[...] lento, gradual e seguro" para a formalização da democratização no Brasil (RAMOS in LEAL; FRIEDRICH [Orgs.], 2013,

\footnotetext{
${ }^{16}$ Ato Institucional n. ${ }^{\circ}$ 01, baixado em 09 de abril de 1964, pelos "comandantes do Exército, da Marinha e da Aeronáutica". Sob a vigência do AI-1, houve a cassação de mandatos a nível municipal, estadual e federal, além da suspensão de direitos políticos por até 10 anos. Houve a criação de Inquéritos Policial-Militares (IPMs), dando conta de investigações a supostos "inimigos internos", desencadeando o processo d prisões arbitrárias e a prática abusiva de tortura. Os militares intervieram em "sindicatos e federações", além do aprisionamento de dirigentes sindicais (FAUSTO, 1999, p.464 - 467).

${ }^{17}$ Baixa do Ato Institucional n. ${ }^{\circ}$ 02, em 17 de outubro de 1965, sob o comando de Castelo Branco (FAUSTO, 1999, p. 474). "O conceito de segurança nacional abarca as ideias de integridade do território, proteção do povo e preservação dos interesses nacionais contra qualquer tipo de ameaça e agressão" (COMISSÃO NACIONAL DA VERDADE, 2014, p.337).

${ }^{18}$ No governo de Castelo Branco, baixou-se em fevereiro de 1966, o Ato Institucional no .03 (FAUSTO, 1999, p. 474).

${ }^{19}$ Castelo Branco determinou o fechamento do Congresso Nacional em outubro de 1966, durante o período de um mês, através do Ato institucional n. 04 (FAUSTO, 1999, p. 475).

${ }^{20}$ Com a baixa do Ato Institucional n. ${ }^{\circ}$ 05, o Presidente da República obteve plenos poderes para decretar o fechamento do Congresso, "cassar mandatos e suspender direitos políticos, assim como para demitir ou aposentar servidores públicos", além de nomear interventores em municípios e estados. Não obstante, suspendeu-se a garantia do habeas corpus aos acusados de praticarem crimes contra a segurança nacional. Houve a prática da censura "aos meios de comunicação; a tortura passou a fazer parte integrante dos métodos do governo". Este período caracterizou-se pelo chamado "Anos de Chumbo", em razão de o Estado brasileiro ter o total controle sobre a mídia, educação, prisão, tortura, educação, censura, assassinato e desaparecimento forçado (FAUSTO, 1999, p.480).
}

Revista Brasileira de Direitos e Garantias Fundamentais | e-ISSN: 2526-0111 | Porto Alegre | v. 4 | n. 2 | p. 18 - 37 | Jul/Dez. 2018 
p.79). A partir disso, a sociedade civil se organiza com o fim de "[...] acelerar o processo de queda dos militares" (PIOVESAN, 2014, p.545).

Assim, em novembro de 1983 a abril de 1984, a população “[...] se fortalece, mediante formas de organização, mobilização e articulação, que permitiram importantes conquistas sociais e políticas". Tanto o é que em 1985 procede-se a realização de eleições diretas para presidente e vice-presidente da República, momento em que Tancredo Neves e seu vice José Sarney foram eleitos, sendo o primeiro presidente civil, precedido do poder militar. Logo, os militares alocaram-se sob o controle institucional civil, sem nenhum papel político relevante (MERLINO; OJEDA, 2010, p.154).

Mais tarde, surge a necessidade de elaboração de um novo código que protegesse não somente direitos individuais, mas também coletivos, “[...] como as associações, entidades de classe, sindicatos [...]" e difusos, "[...] a esse respeito, basta comparar a denominação atribuída ao Capítulo I do Título II da Constituição de 1988 - 'Dos direitos e deveres individuais e coletivos' - com a Constituição anterior, que consagrava tão somente direitos e garantias individuais" (PIOVESAN, 2014, p.546 - p.491) ${ }^{21}$. Por assim dizer, corroboram-se direitos fundamentais ${ }^{22}$ e direitos humanos ${ }^{23}$ indissolúveis aos princípios básicos da vida humana, como fim de refazer "o pacto político-social" (PIOVESAN, 2014, p.545).

Por essa razão, em 05 de outubro de 1988 promulga-se uma "[...] nova ordem constitucional”, sendo “[...] o marco jurídico da transição democrática e da institucionalização dos direitos humanos no País". Dessa forma, houve a instauração de uma Federação e Democracia, a separação dos poderes e o implemento dos "[...] direitos fundamentais, à luz do princípio da dignidade humana" (PIOVESAN, 2014, p.545-546).

Além dessas novidades, houve “[...] novas garantias constitucionais, [...], como o mandado de injunção, o habeas data e o mandado de segurança coletivo, ao mesmo tempo em

\footnotetext{
${ }^{21}$ Estes dois novos componentes - direitos individuais e coletivos - "dos Direitos Fundamentais dos seres humanos passa, a partir deste momento, a formar um novo todo indivisível dos Direitos Humanos no início do século" (MAGALHÃES, 2000, p. 31).

22 “"...] são aqueles direitos, 'matrizes de todos os demais; são direitos sem os quais não podemos exercer muitos outros. São os direitos fundamentais, direitos que dão fundamento a todos os demais" (JOAQUIM CARLOS SALGADO APUD MAGALHÃES, 2000, p.05).

23 “[...] que, no período do regime militar ditatorial, centrava-se, fundamentalmente, na defesa de direitos civis e políticos, como forma de resistência às perseguições políticos-ideológicas, às detenções arbitrárias, aos casos de tortura e de desaparecimento forçado". Mais tarde, os direitos fundamentais e a dignidade da pessoa humana passam a exercer papel fundamental, uma vez que constrói "os princípios constitucionais que incorporam as exigências de justiça e de valores éticos, conferindo suporte axiológico a todo o sistema jurídico brasileiro" (PIOVESAN, 2014, p. 547 - p. 61).
} 
que amplia o objeto de ação popular e da ação civil pública" ${ }^{24}$. Não obstante, no artigo $1^{\circ}$, parágrafo único, cumulado com o artigo 14 da Constituição Federal, há a previsão de que a “[...] soberania popular será exercida pelo sufrágio universal e pelo voto direto e secreto" (PIOVESAN, 2014, p.546).

Segundo a obra de Piovesan, a Magna Carta "[...] encontra-se, ainda, em absoluta harmonia com a concepção contemporânea de direitos humanos, caracterizada pela universalidade $^{25}$ e indivisibilidade de direitos" ${ }^{26}$. No artigo $1^{\circ}$, inciso III da Constituição Federal Brasileira de 1988, prevê como direitos fundamentais a dignidade da pessoa humana em um Estado Democrático de Direito. Por assim dizer, a Carta Magna torna-se símbolo de referência de consolidação, abrangência e avanço na previsão de haver “[...] capítulos dedicados aos direitos e garantias, para então tratar do Estado, de sua organização e do exercício dos poderes" (PIOVESAN in ANDRADE; REDIN [Orgs.], 2008, p.62).

Ademais, dentro da norma constituinte, observa-se a previsão de “[...] no Título II se utiliza dessa expressão: 'Dos Direitos e Garantias Fundamentais' e o Capítulo I tem por título 'Dos Direitos e Deveres Individuais e Coletivos' e o Capítulo II 'Dos Direitos Sociais', dando ênfase e prioridade aos direitos humanos" (MELLO, 1997, p.11).

A partir disso, “[...] os direitos e garantias individuais” são elencados como cláusulas pétreas $^{27}$, previsto no artigo 60 , parágrafo $4^{\circ}$, inciso IV, da Constituição Federal, "[...] passando a compor o núcleo material intangível”, apresentando “[...] o maior grau de legitimidade popular", uma vez que a Carta de 1988 foi a que "[...] mais assegurou a participação popular em seu processo de elaboração". Por esta razão, “[...] conclui-se que esta cláusula alcança os direitos sociais" (PIOVESAN in ANDRADE; REDIN [Orgs.], 2008, p.62).

Em se tratando de direitos humanos, destaca-se, historicamente, seu surgimento a partir “[...] da Declaração Universal de 1948 e reiterada pela Declaração de Direitos Humanos de Viena de 1993" (PIOVESAN, 2014, p.204). Para Bobbio, “[...] os direitos humanos não

\footnotetext{
24 “[...] que passa a tutelar todo e qualquer direito difuso ou coletivo" (PIOVESAN, 2014, p.546).

25 "[...] conferir cumprimento às obrigações internacionais assumidas relativamente aos direitos humanos, decorrentes dos tratados de direitos humanos ratificados pelo Brasil” (PIOVESAN, 2014, p.503).

26 "[...] cabe ao Estado brasileiro a proteção e defesa dos direitos civis e políticos, bem como a implementação e realização dos direitos econômicos, sociais e culturais (PIOVESAN, 2014, p.501).

${ }^{27}$ Trata-se de um dispositivo constitucional que o legislador está impedido de alterá-lo, mesmo se tratando de Proposta de Emenda. Observa-se que a cláusula pétrea pode ser modificada, com o fim de ampliar direitos ou criar novos direitos, desde que não seja retirado um direito fundamental, previsto no artigo $60, \S 4^{\circ}$, da Constituição Federal brasileira.
}

Revista Brasileira de Direitos e Garantias Fundamentais | e-ISSN: 2526-0111 | Porto Alegre | v. 4 | n. 2 | p. 18 - 37 | Jul/Dez. 2018 
nascem todos de uma vez. Nascem quando devem ou podem nascer. Nascem quando o aumento do poder do homem sobre o homem". Isso significar dizer que na normativa sistemática brasileira, os direitos humanos surgiram em um momento histórico de plena complexibilidade, onde direitos individuais ${ }^{28}$, sociais $^{29}$, econômicos ${ }^{30}$ e políticos ${ }^{31}$, foram totalmente suprimidos, urgindo a necessidade da elaboração de uma nova Constituição (2004, p.06).

Segundo Bobbio, direitos humanos podem ser definidos como:

um construído jurídico historicamente voltado para o aprimoramento político da convivência coletiva. É uma quimera buscar um único e absoluto fundamento para os direitos humanos como aspira, de forma recorrente, o moralismo jurídico de corte jus naturalista $(2004$, p. IX).

Com isso, conclui-se que "Os direitos humanos compõem, assim, uma unidade indivisível, interdependente e inter-relacionada, capaz de conjugar o catálogo de direitos civis e políticos com o catálogo de direitos sociais, econômicos e culturais" (PIOVESAN, 2014, p.170). Entende-se que o "Direito Internacional dos Direitos Humanos vem instaurar o processo de redefinição do próprio conceito de cidadania ${ }^{32}$, no âmbito brasileiro" (PIOVESAN, 2014, p.90).

Nota-se que tanto a universalidade quanto a indivisibilidade de direitos são indispensáveis na formação da cidadania, pois cabe ao Estado responsabilizar-se: “[...] de observar, proteger e promover [...] dever jurídico-constitucional, [...] bem como respeitar o processo de especificação do sujeito de direito" (PIOVESAN, 2014, p.504).

Em suma, a responsabilidade do Estado na consolidação da cidadania está condicionada ao fortalecimento de estratégias que sejam capazes de implementar os

\footnotetext{
28 “[...] será a liberdade, sendo estes direitos são relativos à vida, liberdade, propriedade, segurança e igualdade" (MAGALHÃES, 2000, p.02).

29 “[...] os direitos relativos à saúde, educação, previdência e assistência social, lazer, trabalho, segurança e transporte". Em se tratando de direito social à educação, Magalhães ressalta a importância daquela para a formação liberal da "sua consciência política, filosófica e religiosa e ter meios, ou capacidade de expressar esta consciência” (MAGALHÃES, 2000, p. 03 - p. 31).

30، “...] direitos que estão contidos em normas de conteúdo econômico, que viabilizarão uma política econômica. [...] contêm normas que estão protegendo interesses individuais, coletivos e difusos" (MAGALHÃES, 2000, p.03).

31،São direitos de participação popular no Poder do Estado, que resguardam a vontade manifestada individualmente por cada eleitor" (MAGALHÃES, 2000, p.03).

32 “[...] se vê, assim, alargado e ampliado, na medida em que passa a incluir não apenas direitos previstos no plano nacional, mas também direitos internacionalmente enunciados" (PIOVESAN, 2014, p.90).
}

Revista Brasileira de Direitos e Garantias Fundamentais | e-ISSN: 2526-0111 | Porto Alegre | v. 4 | n. 2 | p. $18-37$ | Jul/Dez. 2018 
três elementos essenciais à cidadania plena, quais sejam, a indivisibilidade e a universalidade dos direitos humanos e o processo de especificação do sujeito de direito (PIOVESAN, 2014, p.503).

Por esta razão, considera-se que com o advento da Constituição Cidadã “[...] assegurou a participação popular em seu processo de elaboração, a partir do recebimento de elevado número de emendas populares. É assim, a Constituição que apresenta o maior grau de legitimidade popular" (PIOVESAN, 2014, p.367). Diante disso, cidadãos brasileiros possuem a legitimidade de inspecionar e julgar se os Estados e Governos estão cumprindo com sua função social de respeitar "[...] os direitos fundamentais da pessoa humana" (CONSUL in ANDRADE; REDIN [Orgs.], 2008, p.184). Importante salientar que:

\begin{abstract}
somente a partir do processo de democratização do País, deflagrado em 1985, é que o Estado brasileiro passou a ratificar relevantes tratados internacionais de direitos humanos. O marco inicial do processo de incorporação de tratados internacionais de direitos humanos pelo Direito brasileiro foi a ratificação, em 1989, da Convenção contra a Tortura e Outros Tratamentos Cruéis, Desumanos ou Degradantes. A partir dessa ratificação, inúmeros outros importantes instrumentos internacionais de proteção dos direitos humanos foram também incorporados pelo Direito brasileiro, sob a égide da Constituição Federal de 1988 (PIOVESAN, 2014, p.59).
\end{abstract}

Nessa ótica, “[...] importantes tratados internacionais de direitos humanos foram ratificados pelo Brasil”. Dentre eles, destaque-se a ratificação:

a) da Convenção Interamericana para Prevenir e Punir a Tortura, em 20 de julho de 1989; b) da Convenção contra a Tortura e outros Tratamentos Cruéis, Desumanos ou Degradantes, em 28 de setembro de $1989{ }^{33}$; f) da Convenção Americana de Direitos Humanos, em 25 de setembro de $1992 ;{ }^{34}$; o) do Protocolo Facultativo à Convenção contra a Tortura, em 11 de janeiro de $2007 ;^{35}$ (PIOVESAN, 2014, p.59).

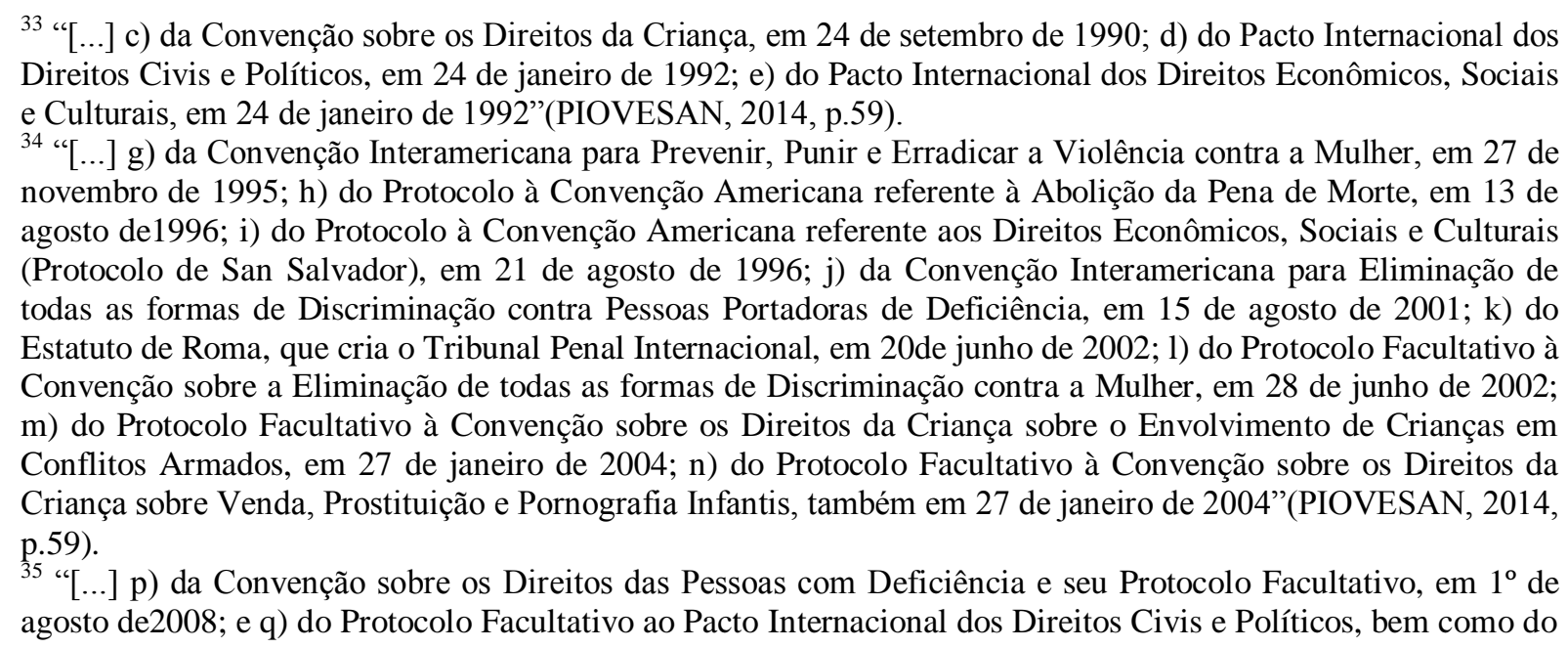

Revista Brasileira de Direitos e Garantias Fundamentais | e-ISSN: 2526-0111 | Porto Alegre | v. 4 | n. 2 | p. $18-37$ | Jul/Dez. 2018 
Percebe-se, portanto, que o desenvolvimento da democratização no Brasil “[...] permitiu a ratificação de relevantes tratados de direitos humanos por sua vez essa ratificação permitiu o fortalecimento do processo democrático, mediante a ampliação e o reforço do universo de direitos por ele assegurado" (PIOVESAN, 2014, p.60). Isso se explica, pois, a Constituição consagra os direitos humanos como princípio fundamental, indispensável na estrutura basilar do topo da pirâmide legislativa e nas relações internacionais (PIOVESAN in ANDRADE; REDIN [Orgs.], 2008, p.66).

Assim, mostra-se evidente a ruptura dos direitos humanos, constituindo-se, principalmente em danos morais, imateriais, danos físicos, psíquicos e danos materiais, tanto para a vítima como sua família. Verifica-se, portanto, inúmeras violações durante o período ditatorial, em que os considerados opositores do regime foram alvos de barbáries em série, ficando marcados para sempre em sua memória e na de todos que vivenciaram esta época.

\section{CONCLUSÃO}

Arraigada em manobras políticas, a ditadura militar brasileira (1964-1985) infringiu as disposições legais pertinentes à época, sobretudo, a Constituinte. Violou direitos fundamentais e exterminou qualquer cidadão que se opusesse ao poder imanente. A garantia à à memória e à verdade dos atos praticados durante o período ditatorial perfaz garantias intrínsecas aos direitos humanos, não apenas das vítimas, como de seus familiares e à comunidade.

A divisão do trabalho, possibilitou, primeiramente, o aprofundamento da análise das violações aos direitos humanos no período militar, apontando os métodos e descrevendo os instrumentos utilizados para as práticas de torturas contra os vitimizados. Nesse sentido, a pesquisa apresentou, inicialmente, como problema central analisar de que forma o estudo sobre as violações dos direitos humanos ocorridos durante a ditadura militar no Brasil influenciam no resgate histórico nacional?

Com efeito, ao longo da pesquisa, afirmou-se a hipótese de que é de essencial importância o resgate histórico para a população brasileira, objetivando o não esquecimento e a não repetição. Oportunizar às presentes e futuras gerações a verdade histórica.

Segundo Protocolo ao mesmo Pacto visando à Abolição da Pena de Morte, em 25 de setembro de 2009"(PIOVESAN, 2014, p.59).

Revista Brasileira de Direitos e Garantias Fundamentais | e-ISSN: 2526-0111 | Porto Alegre | v. 4 | n. 2 | p. $18-37$ | Jul/Dez. 2018 
Através do estudo, afirma-se que o tema abordado é de derradeira importância na medida em que se denota que a história revela, de forma dolorosa, que a imposição autoritária, por parte do Estado, de uma ideologia política torna instável a harmonia social.

São exatamente estes fatores que se busca evitar ao analisar-se a história. No passado o povo buscava o exato cumprimento da lei. Hoje a história não é diferente; em face ao Estado opressor, a sociedade cobra respostas aos atos desumanos e às graves violações de direitos humanos ocorridas naquele período negro da história. Em um sentido ético, o Estado, como ente opressor, deve reparar os danos ocasionados de forma não invasiva, ou seja, de modo a não infligir mais sofrimento às vitimas e/ou familiares.

\section{REFERÊNCIA}

AMNISTÍA INTERNACIONAL. Acabar Con la Imupunidad: justicia para lãs víctimas de tortura. Editora EDAI, 2001.

ARANTES, Maria Auxiliadora de Almeida Cunha. Dor e Desamparo - Filhos e Pais: 40Anos depois. v. 20, n. 2. Rio de Janeiro: PSIC. CLIN., 2008.

ARNS, Dom Paulo Evaristo. Brasil: Nunca mais. 20. ed. Petrópolis/RJ: Editora Vozes, 1987.

BOBBIO, Norberto. A Era dos Direitos. Tradução de Carlos Nelson Coutinho. Rio de Janeiro: Editora Elsevier, 2004.

CAPEZ, Fernando. Curso de direito penal, parte especial: dos crimes contra a dignidade sexual a dos crimes contra a administração pública (arts. 213 a 359-H). 10. ed, v. 3. São Paulo: Editora Saraiva, 2012.

COIMBRA, Cecília Maria Bouças. A eficácia da lei de tortura. Revista do Centro de Estudos Judiciários. Conselho da justiça federal. n. 14. Brasília, 2001.

COMISSÃO NACIONAL DA VERDADE. Relatório da Comissão Nacional da Verdade: 2014. Disponível em: < http://cnv.memoriasreveladas.gov.br/relat\%C3\%B3rios.html>. Acesso em: 25 jul. 2018, 16:29:50. 
CONSUL, Júlio Cesar Dal Paz. Direitos Humanos e Segurança Nacional. In: ANDRADE, Jair; REDIN, Giuliana. Múltiplos Olhares sobre os Direitos Humanos. Passo Fundo: Editora IMED, 2008.

FAUSTO, Boris. História do Brasil. 7. ed. São Paulo: Editora USP, 1999.

FERREIRA, Aurélio Buarque de Holanda. Dicionário Aurélio da Língua Portuguesa. 5. ed. Curitiba: Editora Positivo, 2010.

FICO, Carlos. História do Tempo Presente, eventos traumáticos e documentos sensíveis: o caso brasileiro. Varia Historia. v. 28, n. 47. Belo Horizonte, 2012.

Versões e controvérsias sobre 1964 e a ditadura militar. Revista: Revista Brasileira de História, v. 24, n. 47. São Paulo, 2004.

MAGALHÃES, José Luiz Quadros. Direitos Humanos: sua história, sua garantia e a questão da indivisibilidade. São Paulo: Juarez de Oliveira, 2000.

MATTOSO, Glauco. O que é Tortura. São Paulo: Brasiliense, 1984. (Primeiros passos)

MELlO, Celso D. de Albuquerque. Direitos Humanos e Conflitos Armados. Rio de Janeiro: Editora Ronovar, 1997.

MERLINO, Tatiana; OJEDA, Igor. Direito à memória e à verdade: Luta, substantivo feminino. São Paulo: Editora Caros Amigos, 2010.

OLIVEIRA, Luciano. Ditadura Militar, Tortura e História: A "vitória simbólica” dos vencidos. Revista: Revista Brasileira de Ciências Sociais. v. 26, n. 75, 2011.

PIOVESAN, Flávia. Desenvolvimento histórico dos direitos humanos e a Constituição Brasileira de 1988. In: ANDRADE, Jair; REDIN, Giuliana. Múltiplos Olhares sobre os Direitos Humanos. Passo Fundo: Editora IMED, 2008.

Temas de direitos humanos. 7. ed. São Paulo: Editora Saraiva, 2014.

Revista Brasileira de Direitos e Garantias Fundamentais | e-ISSN: 2526-0111 | Porto Alegre | v. 4 | n. 2 | p. 18 - 37 | Jul/Dez. 2018 
RAMOS, Taís. A Justiça de Transição e a Revitalização da Democracia em face das Violações de Direitos Humanos Decorrentes do Regime Militar Brasileiro. In: LEAL, Rogério Gesta; FRIEDRICH, Denise Bittencourt. Imbricações políticas e jurídicas na constituição da verdade, memória e justiça de transição no Brasil. Santa Cruz do Sul: Editora Edunisc, 2013.

SILVA FILHO, José Carlos Moreira. O Anjo da História e a Memória das Vítimas: O Caso Da Ditadura Militar No Brasil. v. 53, n. 2. Porto Alegre: Editora Veritas, 2008. 